\title{
POCUS echocardiography in massive pulmonary thromboembolism as a first manifestation of COVID-19 infection: a case report
}

\author{
(DIrena Mitevska* \\ University Cardiology Clinic, \\ Skopje, North Macedonia
}

KEYWORDS: COVID-19, pulmonary thromboembolism, cardiogenic shock, echocardiography.

CITATION: Cardiol Croat. 2021;16(5-6):178. | https://doi.org/10.15836/ccar2021.178

*ADDRESS FOR CORRESPONDENCE: Irena Mitevska, University Cardiology Clinic, Ul. Vodnjanska 17, 1000 Skopje, North Macedonia. / Phone: +389-75-491-216 / E-mail: peovskai@yahoo.com

ORCID: Irena Mitevska, https://orcid.org/0000-0002-2774-8559

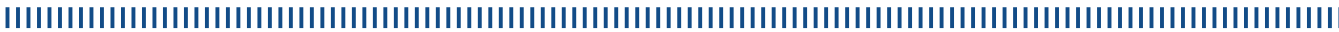

Introduction: COVID-19 infection significantly increases the risk for thromboembolic complications which can cause multi organ dysfunctions and worsen patients clinical course and prognosis. ${ }^{1-3}$

Case report: We are presenting a 73-years-old patient admitted to ICU unit due to first episode of sudden dyspnea, syncope and chest pain. He has no history of previous cardiovascular or respiratory disease, no history of thromboembolism (PTE) or deep vein thrombosis (DVT). ECG showed atrial fibrillation with HR $120 \mathrm{bpm}$ and incomplete RBBB. Blood pressure was $85 / 45 \mathrm{mmHg}$ with cold periphery. Patient denied any provocable PE risk factors. Bed site POCUS (Point-of-Care Ultrasound) echocardiography was performed immediately in order to evaluate the cause of patient symptoms and hemodynamic instability. Examination showed increased right ventricle (RV) size, reduced RV function (TAPSE 13, TDI S' 9), presence of McConnell's sign, severe tricuspid regurgitation with dilated v. cava and signs of pulmonary hypertension. Due to hemodynamic instability and indirect signs of the presence pf pulmonary embolism fibrinolysis with alteplase infusion was applied. Patient hemodynamically stabilized after first hour. Nasopharyngeal smear for SARV CoV-2 was taken due to ongoing pandemic and result come out positive for virus RNK (real-time fluorescence polymerase chain reaction-PCR). CT angiography was performed which showed large intraluminal thrombi in the right pulmonary artery, extending to left pulmonary artery up to subsegmental level. His D-dimer values were $7813 \mathrm{ng} / \mathrm{ml}$, CRP $123 \mathrm{mg} / \mathrm{L}$. Evaluated sPESI score was 2, which indicated elevated 30-day death risk. Patient remained clinically stable. He was transferred to the infectious disease clinic for further treatment. After two weeks was discharged with recommendations for three months anticoagulation treatment with Rivaroxaban. Patient performed control visit at our clinic after four months. He was stable, asymptomatic with normal right ventricular function.

Conclusion: This is case of successful treatment of pulmonary embolism complicated with cardiogenic shock as a first manifestation of COVID-19 infection at our clinic since the start of pandemic. POCUS echocardiography is fast noninvasive method that help us urgently assess the cause of patient instability and guide diagnostic approach and patient management.
RECEIVED:

March 28, 2021

ACCEPTED:

April 2, 2021

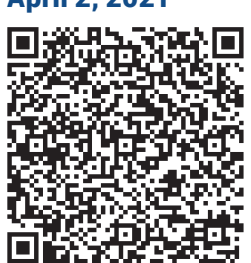

$\square$ Cardiologia Croatica 2021;16(5-6):178.
CroEcho2021

$11^{\text {th }}$ Croatian Biennal Echocardiography Congress with International Participation / 11. hrvatski dvogodišnji ehokardiografski kongres s međunarodnim sudjelovanjem Virtual Congress, May 6-8, 2021

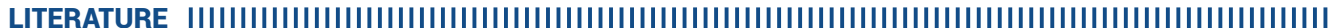

1. Borloz MP, Frohna WJ, Phillips CA, Antonis MS. Emergency department focused bedside echocardiography in massive pulmonary embolism. J Emerg Med. 2011 Dec;41(6):658-60. https://doi.org/10.1016/j.jemermed.2011.05.044

2. Casazza F, Bongarzoni A, Capozi A, Agostoni 0. Regional right ventricular dysfunction in acute pulmonary embolism and right ventricular infarction. Eur J Echocardiogr. 2005 Jan;6(1):11-4. https://doi.org/10.1016/j.euje.2004.06.002

3. Danzi GB, Loffi M, Galeazzi G, Gherbesi E. Acute pulmonary embolism and COVID-19 pneumonia: a random association? Eur Heart J. 2020 May 14:41(19):1858. https://doi.org/10.1093/eurheartj/ehaa254 